\title{
Perceraian Akibat Dampak Covid-19 dalam Perspektif Hukum Islam dan Perundang-undangan di Indonesia
}

\author{
Robiah Awaliyah" ${ }^{1}$, Wahyudin Darmalaksana ${ }^{2 *}$ \\ 1,2Jurusan Ilmu Hadis Fakultas Ushuluddin, UIN Sunan Gunung Djati Bandung, Indonesia \\ *Corresponding Author Email:yudidarma@uinsgd.ac.id
}

\begin{abstract}
This study aims to discuss solutions to prevent divorce, which continues to increase due to the impact of the Covid-19 pandemic. This research is a qualitative type that applies literature study by applying the approach of Islamic law and legislation in force in Indonesia. The results and discussion of this research include the phenomen on of divorce during the Covid-19 pandemic, divorce in Islamic law and legislation in Indonesia and solutions to prevent divorce due to the impact of Covid-19. This study concludes that Islamic law and legislation in Indonesia has the best way to deal with every problem of its people, induding problems that arise in the household, especially due to the impact of Covid-19, which can not be found for solutions except for divorce. This research recommends efforts to prevent divorce during the Covid-19 pandemic through the roles of government, religious leaders, communities, families to their own awareness.
\end{abstract}

Keywords: Constitution, Covid-19, Data Analysis, Divorce, Islamic Law

\begin{abstract}
ABSTRAK
Penelitian ini bertujuan untuk membahas solusi pencegahan perceraian yang terus meningkat akibat dampak pandemi Covid-19. Penelitian ini merupakan jenis kualitatif yang menerapkan studi pustaka literatur dengan menerapkan pendekatan hukum Islam dan perundang-udangan yang berlaku di Indonesia. Hasil dan pembahasan penelitian ini mencakup fenomena perceraian pada masa pandemi Covid-19, perceraian dalam hukum Islam dan perundang-undangan di Indonesia dan solusi pencegahan perceraian akibat dampak Covid-19. Penelitian ini menyimpulkan bahwa hukum Islam dan perundangundangan di Indonesia memiliki jalan terbaik dalam menghadapi setiap permasalahan umatnya, termasuk permasalahan yang muncul dalam rumah tangga terlebih karena dampak Covid-19 yang tidak bisa dicari solusi kecuali perceraian. Penelitian ini merekomendasikan upaya-upaya pencegahan perceraian di masa pandemi Covid-19 melalui peran pemerintah, tokoh agama, masyarakat, keluarga hingga dengan kesadaran sendiri.
\end{abstract}

Kata Kunci: Analisis Data, Covid-19, Hukum Islam, Perceraian, Undang-Undang

\section{PENDAHULUAN}

Covid-19 menyumbangkan angka perceraian dalam jumlah yang tinggi di Indonesia. Saat awal penerapan pembatasan sosial berskala besar(PSBB) pada April dan Mei 2020, perceraian di Indonesia di bawah 20.000 kasus, namun pada bulan Juni dan Juli 2020, jumlah perceraian meningkat menjadi 57.000 kasus (Hidayati, 2021; Subardhini, 2021).Perceraian di Indonesia meningkat sebesar 5\% sepanjangmasa Covid-19, karena sebagian keluarga mengalami kesulitan dalam ekonomi (Fauziah et al.,2020).Penerapan PSBB sebagai aturan protokol kesehatan Covid-19 di Indonesia telah menurunkan aktivitas ekonomi, sebagai akibatnya menurun pula pendapatan ekonomi keluarga, hal ini membawa dampak terhadap meningkatnya kekerasan dalam rumah tangga (KDRT), dan pada akhirnya terjadi perceraian (Radhitya et al., 2020). Hal ini tentu saja merupakan kenyataan yang memprihatinkan. Oleh karena itu, problem

* Copyright (c) 2021 Robiah Awaliyah dan Wahyudin Darmalaksana

This work is licensed under a Creative Commons Attribution-ShareAlike 4.0 International License. 
perceraian di Indonesia sebagainegara dengan penduduk mayoritas muslim harus dapat diatasi melalui hukum Islam dan perundang-undangan seiring dengan masa pandemi Covid-19 yang menyebar di seluruh dunia.

Para ahli tampak telah melakukan berbagai penelitian terkait dengan dampak Covid-19 terhadap perceraian di Indonesia. Antara lain Subardhini, M. (2021), "Perceraian Di Masa Pandemi Covid-19: Masalah dan Solusi," Politeknik Kesejahteraan Sosial Bandung. Penelitian kualitatif ini menerapkan studi kasus di Kota Bandung. Hasil dan pembahasan penelitian ini memaparkan bahwa s ecara umum faktor penyebab perceraian pada masa pandemi Covid-19 terjadi karena adanya konflik dalam rumah tangga yang disebabkan oleh permasalahan ekonomi, ketidakseimbangan aktivitas dan waktu bersama, KDRT, berubah pola komunikasi, dan faktor usia dalam membina rumah tangga. Penelitian ini menyimpulkan bahwa inti perceraian adalah karena tidak ada keharmonisan. Penelitian ini merekomendasikan perlu adanya pola pencegahan agar tidak terjadinya perceraian dalam mengatasi masalah perkawinan (Subardhini, 2021). Hidayati, L. (2021), "Fenomena Tingginya Angka Perceraian Di Indonesia Antara Pandemi dan Solusi," Khuluqiyya. Penelitian ini menerapkan jenis kualitatif melalui pendekatan fenomenologis. Hasil dan pembahasan penelitian ini menjelaskan bahwa agama Islam memperbolehkan perceraian meskipun dibenci oleh Allah Swt., namun, cara-cara yang baik dalam pencegahan perceraian perlu ditempuh. Penelitian ini menyimpulkan bahwa pencegahan merupakan solusi terbaik untuk menekan tingkat perceraian di Indonesia. Penelitian ini merekomendasikan untuk meningkatkan peran kontrol Kementerian Agama, pengawas agama, para ulama dan kiyai, tokoh masyarakat, dan perguruan tinggi dalam melakukan sinergi bagi pencegahan angka perceraian di Indonesia (Hidayati, 2021). Fauziah, A. S. N., Fauzi, A. N., \& Ainayah, U. (2020), “Analisis Maraknya Perceraian Pada Masa Covid-19," Mizan: Journal of Islamic Law. Penelitian ini menerapkan jenis kualitatif dengan analisis hukum Islam. Hasil dan pembahasan penelitian ini menunjukkan bahwa perceraian di Indonesia tidak dapat sepenuhnya menerapkan hukum Islam secara lisan tetapi dibutuhkan perundang-undangan untuk mengatur agar salah satu pihak tidak dirugikan. Penelitian ini menyimpulkan bahwa perkawinan merupakan pondasi keluarga dan perceraian berarti putusnya hubungan suami-istri karena suatu alasan. Penelitian ini merekomendasikan penguatan hukum Islam dan sekaligus perundang-undangan tentang perceraian seiring pandemi Covid-19 di Indonesia(Fauziah etal., 2020).

Tentu masih banyak penelitian tentang dampak Covid-19 terhadap perceraian, namun sejumlah penelitian yang dipaparakan terdahulu dipandang cukup bagi penyusunan kerangka berpikir penelitian ini. Covid-19 merupakan fenomena wabah yang melanda seluruh dunia hingga membawa dampak yang luas terhadap berbagai segmen kehidupan, terutama bidang ekonomi (Abdi, 2020; Yamali \& Putri, 2020). Sebagai upaya pencegahan pandemi Covid-19, muncul konsep social distancing dan lockdown (Herdiana, 2020) yang dalam penerapan di Indonesia dikenal dengan PSBB (Hasrul,2020). PSBB ternyata memiliki dampak terhadap kerugian ekonomi nasional (Hadiwardoyo, 2020), hal ini dirasakan pula dampaknya oleh masyarakat berpenghasilan rendah (Nasruddin \& Haq, 2020). Kerugian ekonomi masyarakat pada masa pandemi Covid-19 membawa dampak susulan berupa meningkatnya angka perceraian di Ind onesia (Fauziah et al., 2020; Hidayati, 2021; Radhitya et al., 2020; Subardhini, 2021). Perceraian telah diatur dalam hukum Islam (Azizah, 2012) dan perundang-undangan di Indonesia (Rodliyah, 2014). Perceraian sendiri adalah terputusnya status ikatan suami istri disebabkan alasan tertentu (Abror \& MH, 2020). Perceraian merupakan problem dalam kehidupan keluarga (Riami, 2020) dan sekaligus perceraian membawa dampak yang luas pula (Siregar, 2015). Islam memperbolehkan perceraian bila hubungan suami istri tidak dapat dipertahankan lagi kecuali cerai sebagai jalan yang terbaik (Abror \& MH, 2020; Azizah, 2012). Mengingat Indonesia merupakan negara hukum dan mayoritas penduduk Indonesia 
beragama Islam, sehingga dibutuhkan asimilasi hukum Islam dalam perundang-undangan yang mengatur perceraian di tanah air (Azizah, 2012; Rodliyah, 2014). Perceraian tanpa melibatkan aspek hukum perundangan-undangan yang berlaku dapat membawa dampak-dampak buruk yang tidak diharapkan (Rodliyah, 2014), hal ini menjadi perhatian berbagai pihak terutama seiring dengan kenyataan meningkatnya angka perceraian akibat pademi Covid-19 di Indonesia (Fauziah et al., 2020; Hidayati,2021; Radhitya et al.,2020; Subardhini, 2021).

Berdasarkan paparan di atas, peneliti berusaha menyusun formula penelitian, yaitu rumusan masalah, pertanyaan utama penelitian, dan tujuan penelitian (Darmalaksana, 2020a). Rumusan masalah penelitian ini adalah terdapat solusi pencegahan perceraian yang terus meningkat akibat dampak pandemi Covid-19 melalui perspektif hukum Islam dan perundang-undangan di Indonesia. Pertanyaan utama penelitian ini ialah bagaimana solusi dalam mengatasi persoalan tersebut. Penelitian ini bertujuan untuk membahassolusi pencegahan perceraian yang terus meningkatakibat dampak pandemiCovid-19 sebagaimana dikemukakan dalam rumusan masalah. Penelitian ini diharapkan memiliki manfaat bagi akademisi bidang hukum Islam dalam menyikapi kasus perceraian di masa pandemi Covid-19.

\section{METODOLOGI PENELITIAN}

Penelitian ini merupakan jenis kualitatif melalui studi pustaka (Darmalaksana, 2020) dengan menerapkan pendekatan hukum Islam dan perundang-undangan yang berlaku di Indonesia. Penelitian dilaksanakan dengan menghimpun sumber-sumber kepustakaan, baik sumber primer maupun sekunder. Setelah terhimpun, sumber kepustakaan dikategorikan sesuai sub-sub pertanyaan, yaitu bagaimana fenomena perceraian pada masa Covid-19, bagaimana perceraian dalam hukum Islam dan perundangundangan di Indonesia, dan bagaimana solusi pencegahan perceraian yang terus meningkat akibat dampak Covid-19. Jawaban atas pertanyaan-pertanyaan tersebut yang ditunjang dengan data kepustakaan dipahami sebagai hasil atau temuan penelitian. Selanjutnya, analisis dilakukan terhadap temuan-temuan penelitian tersebut sebagai interpretasi dalam upaya menghasilkan pengetahuan. Bagian pertama digunakan analisis fenomenologis, bagian kedua diterapkan analisis hukum Islam dan perundang-undangan, dan bagian ketiga dilakukan analisis isi (content analysis). Analisis ini dilakukan cukup untuk menarik sebuah kesimpulan.

\section{HASIL DAN PEMBAHASAN}

\section{Fenomena Perceraian Masa Pandemi Covid-19}

Akhir tahun 2019 dunia dihebohkan dengan munculnya wabah penyakit yang men yebar ke berbagai belahan dunia.Wabah penyakit ini bernama Covid-19atau sering disebutdengan Corona Virus. Virus ini diduga berasal darinegara Tiongkok tepatnya di sebuah daerah bernama Wuhan (Khaeruman et al., 2020). Persebaran virus ini begitu cepat karena sangat mudah menyebar dan menular kepada orang lain dengan cara kontak secara langsung maupun tidak langsung dengan penderita, oleh karena itu, organisasi kesehatan dunia (WHO) mengkategorikan keadaan ini sebagai pandemi global (Hidayati, 2021).

Salah satu cara untuk menekan pernyebaran virus ini adalah dengan mengurangi secara ekstrem kegiatan interaksi dengan oranglain serta menghindaritempat keramaian, oleh karenaitu, pemerintah di berbagai negara memberlakukan kebijakan lockdown. Lockdown adalah pembatasan kegiatan keluar rumah atau di Indonesia dikenal dengan pembatasan sosial berskal a besar (PSBB), yaitu semua kegiatan 
yang dilakukan di luar rumah yang dapat menyebabkan terjadinya kerumunan, keramaian atau perkumpulan dihentikan sementara seperti sektor wisata, pendidikan, transportasi umum dan sektor usaha seperti pabrik-pabrik dihentikan sehingga pada akhirnya semua kegiatan dilakukan di rumah, masyarakathanya diperbolehkan keluar rumah jika keadaan sangat mendesak (Abdi, 2020).

Penerapan PSBB sebagai aturan protokol kesehatan Covid-19 di Indonesia telah menurunkan aktivitas ekonomi (Abdi, 2020; Yamali \& Putri, 2020), sebagai akibatnya menurun pula pendapatan ekonomi keluarga, hal ini secara langsung ataupun tidak langsung telah membawa dampak terhadap meningkatnya kekerasan dalam rumah tangga (KDRT), dan pada akhirnya terjadi perceraian (Radhitya et al., 2020). Setelah kebijakan PSBB diberlakukan dan masyarakat berdiam diri di rumah tentu bagi beberapa orang adalah kegiatan yang menyenangkan karena rumah merupakan tempat orang merasa aman, namun bagi beberapa lainnya tidak, karena mereka terperangkap dirumah dengan pasangan atau keluarga yang terkadang melakukan perbuatan kasar hingga tidak terkontrol (Radhitya et al.,2020). Saat awal penerapan PSBB pada April dan Mei 2020, perceraian di Indonesia di bawah 20.000 kasus, namun pada bulan Juni dan Juli 2020, jumlah perceraian meningkat menjadi 57.000 kasus (Hidayati, 2021; Subardhini, 2021).

Memang menurut catatan kantor urusan sipil pengajuan perceraian menurun pada saat PSBB karena diterapkan pembatasan. Namun, setelah kebijakan New Normal diterapkan kantor urusan sipil mendapatkan banyak sekali pengajuan perceraian. Hal ini jelas bahwa fenomena meningkatnya angka perceraian ini merupakan dampak negatif dari Covid-19 (Fauziah et al., 2020). Seperti dikutip dari Kompas TV, bahwa Pengadilan Agama Kelas 1a Kabupaten Garut mencatat kenaikan drastis kasus perceraian di tengah pandemi Covid-19. Setidaknya ada sekitar 3000 kasus gugatan perceraian yang mayoritas disebabkan oleh masalah ekonomi rumah tangga (Hidayati, 2021).

Dilansir dari Kompas.com, Humas Pengadilan Negeri Agama Jakarta Timur, Istiana mengatakan bahwa Pengadilan Negeri Agama Jakarta Timur mencatat ada 900 laporan perceraian yang masuk selama pandemi Covid-19ini. Angka kasustersebut merupakan yang tertinggi dibandingkan dengan wilayah lain di sekitarnya. Istiana juga mengatakan bahwa angka tersebut naik hampir 50 persen dari sebelumnya. Sebelumnya, Pengadilan Negeri Agama Jakarta Timur hanya menerima 450 sampai 500 kasus gugatan perceraian. Dari 900 laporan tersebut berujung pada perceraian. Hanya sedikit yang berakhir di meja mediasi(Marison, 2020).

Jawa Timur dilansir dari Liputan6.com, Ketua Pengadilan Agama Kabupaten Madiun,Zainal Arifin menuturkan bahwa angka perceraian di Madiun sebanyak 1.635 kasus yang merupakan data total cerai gugat dan talak. Untukgugat ceraiyang diajukan oleh istriselama Maret-Agustus 2020ada 1.135 kasus, sedangkan untuk cerai talak atau perceraian yang dilakukan oleh suami selama Maret-Agustus 2020 sebanyak 500 kasus. Zainal juga mengatakan angka kasus gugat cerai paling tinggi terjadi pada Februari 2020 dengan kasus cerai gugat sebanyak 299 kasus, dan cerai talak sebanyak 120 kasus. Zainal menuturkan, masalah yang melatarbelakangi perceraian di Madiun sebagian besar soal ekonomi, antara lain nafkah suami yang dirasa belum cukup dan istri tidak tahan dengan sikap suaminya yang tidak bertanggungjawab, mabuk-mabukan hingga KDRT (Liputan6.com, 2020).

Jakarta Post, menyebutkan bahwa tingkat perceraian meningkat secara signifikan di Bandung, Jawa Barat, yang disebabkan karena pemerintah melonggarkan pembatasan Covid-19atau memasuki era New Normal. Menurut data yang didapatkan, Kantor Pengadilan Agama Bandung menerima 433 permintaan cerai pada bulan Maret 2020 yang kemudian kasus tersebutm enurun pada April 2020 dengan jumlah 103 kasus. Kemudian pada bulan Mei 2020 tercatat sebanyak 207 kasus dan kemudian melonjak drastis sebanyak 706 kasus pada Juni 2020 (Hidayati, 2021). 
Perceraian Akibat Dampak Covid-19 Perspektif Hukum Islam dan Perundang-undangan Di Indonesia Robiah Awaliyah dan Wahyudin Darmalaksana

Di Indonesia angka perceraian memang tinggi pada setiap tahun, terlebih lagi padamasa Covid-19. Perceraian di Indonesia meningkat sebesar 5\% sepanjang masa pandemi Covid-19, hal ini secara umum karena sebagian keluarga mengalami kesulitan dalam ekonomi (Fauziah et al., 2020). Dari kesulitan ekonomi tersebut kemudian berdampak terhadap perceraian. Hal ini tentu merupakan fenomena yang mengkhawatirkan, tetapi itulah kenyataanyang tidak dapat dibantah.

\section{Perceraian Menurut Hukum Islam dan Perundang-undangan}

Islam sangat memperhatikan setiap detail kehidupan umat manusia, sehingga dalam Islam semua hal mengenai kehidupan terdapat aturannya masing-masing, demikian juga dengan masalah hasrat seksual (Hidayati, 2021). Di dalam Islam, umat manusia dilarang untuk menyalurkan hasrat seksualnya secara bebas. Karena itulah, Islam mengatur hasrat seksual tersebut dengan menyerukan kepada pernikahan (Rosele etal., 2013).

Pernikahan adalah penyatuan dua jiwayang berbeda jenis menjadi satu kesatuan yangutuh dalam mewujudkan kesempurnaan hidup. Pernikahan diartikan pula dengan suatu janji suci untuk hidup bersama berstatus sebagai suami-istri dengan tujuan untuk memenuhi petunjukagama, mengikuti sunah Nabi dalam rangka mendirikan keluarga yang harmonis, sejahtera dan bahagia. Harmo nis dalam menjalankan hak dan kewajiban sebagai suami istri, sejahtera dalam menciptakan ketenangan lahir dan batin sehinggatimbullah kebahagiaan (Anwar,2015).

Syari'at Islam menjadikan pernikahan sebagai suatu hubungan yang agung, suci dan kokoh. Sebagaimana terdapat dalam al-Qur'an istilah pertalian itu dengan mitsaq ghalidz (perjanjianyang agung) dalam al-Qur'an surat an-Nisa'ayat 21 menyatakan:

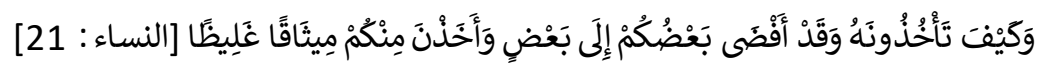

Artinya: "Bagaimana kamu akan mengambilnya kembali, Padahal sebagian kamu telah bergaul (bercampur) dengan yang lain sebagai suami-isteri, mereka (istri-istrimu) telah mengambil dari kamu perjanjian yangkuat" (Indonesia, 2009).

Suami istri wajib menjaga hubungan pernikahan dan tidak sepantasnya memutuskan dan merusak tali pernikahan. Meskipun dalam hukum Islam perceraian merupakan perbuatan halal namun dibenci oleh Allah. Allah memang membenci perceraian, akan tetapiapabila dengan mempertahankan pernikahan itu akan lebih banyak madhorot daripada manfaat, maka perceraian tersebut diperbolehkan (Rodliyah, 2014). Menurut hukum Islam, istilah perceraian disebut sebagai talaq. Talaq sudah ada pada zaman Rasulullah dan para Sahabat (Anwar, 2015). Talak dapat berarti menghilangkan ikatan pernikahan atau mengurangi keterikatannya dengan menggunakan ucapan tertentu, melepaskan ikatan pe nikahan dan mengakhiri hubungan suami istri, serta melepaskan ikatan pernikahan dengan ucapan talak atau yang sepadan denganitu (Hamid, 1988).

Mengenai perceraian, Rasulullah bersabda:

$$
\begin{aligned}
& \text { (3) }
\end{aligned}
$$

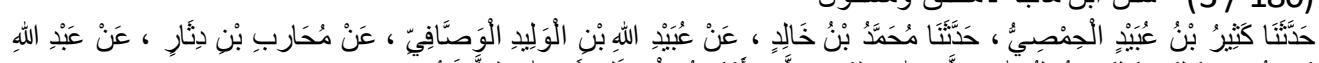

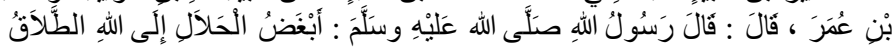

Telah menceritakan kepada kami Katsir bin Ubaidil al-Mihsi, telah menceritakan kepada kami Muhammad bin Kholid, dari Ubaidillah bin walid al-Washofi, dari Muharib bin Ditsar, dari Abdillah bin 
Perceraian Akibat Dampak Covid-19 Perspektif Hukum Islam dan Perundang-undangan Di Indonesia Robiah Awaliyah dan Wahyudin Darmalaksana

Umar, telah berkata Rasulullah SAW: perbuatan halal yang paling dimurkai oleh Allah ialah menjatuhkan thalaq.

Hadis ini diriwayatkan Abu Dawud (2-225) dan Ibnu Majah (1-650) dari Abdullah bin Umar. Shahih menurut Al-Hakim dan as-Suyuthi (Syaikh Al-Munawi, n.d.). Daripada itu, terdapat riwayat lain yang menjelaskan mengenai perceraian, Rasulullah bersabda:

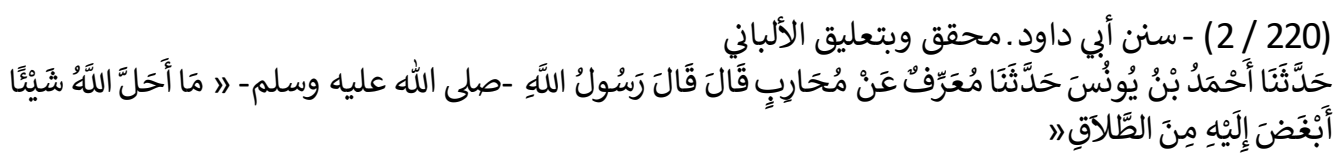

Telah menceritakan kepada kami Ahmad bin Yunus, telah menceritakan kepada kami Muarrif dari Muharib berkata, telah bersabda Rasulullah: Perkara halal yang dibenci oleh Allah adalah cerai. AlMunawi mengatakan bahwa hadis ini shahih atau hasan dan diriwayatkan oleh Al-Hakim No. 2794 (Syaikh Al-Munawi, n.d.). Dari kedua hadis tersebut, jelas bahwasan ya talak atau perceraian merupakan suatu perbuatan yang halal namun dibenci oleh Allah SWT. Menurut Sulaiman Rasjid dalam bukunya Fiqh Islam dilihat dari sisi maslahat dan mudhorot, hukum perceraian dibagi menjadi empat bagian, yaitu: wajib, makruh, sunah dan haram (Rasjid, 2012). Pertama, hukum perceraian menjadi wajib apabila atas putusan hakim dalam hal terjadinya perselisihan yang berkepanjangan antara suami dan istri sudah diadakan upaya perdamaian oleh dua orang hakim, selanjutnya kedua hakim sudah sepakat memandang perlu untuk diadakannya perceraian yang bersifat ba'in sughra (Masriani, 2014).

Kedua, hukum perceraian menjadi haram apabila ikrar talak dilakukan tanpa adanya alasan yang jelas. Karena tidak ada kemaslahatan yang akan dicapai dari perbuatan cerai tersebut (Asmuni, 2016). Ketiga, hukum perceraian menjadi makruh yaitu atas dasar hukum asal dari talak itu sendiri. Keempat, hukum perceraian menjadi sunah apabila suami tidak sanggup lagi membayar serta mencukupi kewajibannya (nafkah) terhadap keluarga atau seorang istri tidak mampu menjaga kehormatan dirinya (Rasjid, 2012).

Undang-Undang Nomor 1 Tahun 1974 Pasal 1 menjelaskan mengenai definisi perkawinan, yaitu suatu perbuatan yang mulia, karena dalam perkawinan terdapat ikatan lahir batin antara seoranglaki-laki dan perempuan sebagai suami istri dengan tujuan membentuk rumah tangga yang bahagia, harmonis dengan mengharap ridho Allah SWT serta kekal berdasarkan Ketuhanan Yang MahaEsa (Burlian, 2019).

Undang-Undang No. 1 Tahun 1974 Pasal 38 tentang Perkawinan menyebutkan bahwa perkawinan dapat diputus karena kematian, perceraian, dan atas keputusan pengadilan (PNH Simanjuntak, 2017). Berdasarkan Pasal 39 Undang-Undang Perkawinan, perceraian perkawinan hanya dapat dilakukan di depan sidang pengadilan setelah pengadilan berusaha untuk tidak menceraikan namun tidakberhasil mendamaikan kedua belah pihak. Serta dalam mengajukan perceraian harusdidasari dengan alasan yang kuat bahwa sudah tidak ada lagi kecocokan (Rodliyah, 2014).

Menurut R. Subekti, perceraian adalah penghapusan perkawinan dengan putusan hakim atas tuntutan salah satu pihak dalam perkawinan. Jadi, dapat disimpulkan bahwa perceraian adalah pembubaran suatu hubungan perkawinan ketika pihak-pihak masih hidup dengan didasarkan pada alasan-alasan yang dapat dibenarkan serta telah ditetapkannya suatu keputusan hakim (Anwar, 2015). Maka dengan adanya perceraian ini perkawinan mereka putus dan diantara mereka sudah tidak ada hubungan suami istri, mereka dibebaskan dari segala kewajiban-kewajiban mereka sebagai suami istri (Rodliyah,2014). 
Perceraian Akibat Dampak Covid-19 Perspektif Hukum Islam dan Perundang-undangan Di Indonesia Robiah Awaliyah dan Wahyudin Darmalaksana

\section{Solusi Pencegahan Perceraian Akibat DampakCovid-19}

Fenomena perceraian yang meningkat karena pandemi Covid-19 ini tentu saja merupakan kenyataan yang memprihatinkan. Oleh karena itu, problem perceraian di Indonesia sebagai negara dengan penduduk mayoritas muslim harus dapat diatasi melalui hukum Islam dan perundang-undangan seiring dengan masa pandemi Covid-19 yang menyebar di seluruh dunia. Kebijakan pemerintah seperti PSBB dalam menekan penyebaran virus Covid-19 yang saat ini mewabah tentu berdampak pada hubungan rumah tangga, berbagai masalah baru muncul dan dapat menyebabkan perceraian (Hidayati, 2021; Subardhini, 2021).

Ada beberapa akibat yang terjadi karena perceraian, baik itu dampak untuk diri sendiri ataupun untuk orang lain, seperti dampak yang terjadi pada anak. Adapun dampak perceraian pada diri sendiri seperti yang dilansir dari Klikdokter.com, perceraian akan memunculkan emosi-emosi negatif, seperti kesedihan, kecemasan, kekhawatiran, bahkan hingga perasaan tidak mampu bertahan hidup. Bahkan, ketika seseorang mengalami stres yang berkepanjangan, dapat mengakibatkan tubuh merespon dengan tidak baik, seperti terjadinya peningkatan tekanan darah, menurunnya sistem kekebal an tubuh, dan reaksi peradangan yang berlebihan. Pada akhirnya, kombinasi dari semua ini akan menimbulkan berbagai gangguan kesehatan, seperti gangguan cemas dan depresi, insomnia, infeksi, gangguan pencernaan, berat badan yang berubah drastis, penyakit jantung dan pembuluh darah, ketergantungan zat tertentu hingga menyebabkan pernyakitkronik dan gangguan mobilitastubuh (Tanamas, 2020).

Dampak terhadap orang lain seperti pada anak, dikutip dari situs Halodoc, jika orangtua bercerai maka anak akan merasa keluarganya sudah tidak lagi sempurna sehingga dapat memunculkan rasa iri terhadap teman-temannya yang seringkali menghabiskan waktu bersama orangtuanya. Anak akan merasa sedih dan kecewa bahkan hingga tidak menerima keadaan yang tentu saja membawa dampak yang tidak kecil, seperti anak memil iki tabiat yang buruk, merasa kualitas kehidupan yang rendah, bahkan hingga anak antisosial dan mengalami penurunan akademik (Halodoc, 2018).

Begitu besar dampak dari perceraian yang tidak hanya dialami oleh pelaku (suami istri), melainkan anak dan keluarga besar kedua belah pihak juga mengalami dampaktersebut. Bahkan, kedua keluarga besar akan mengalami kerenggangan dan keretakan persaudaraan. Mungkin saja berawal dari kesalahpahaman hingga menjadi pertengkaran, percekcokan sampai putusnya persaudaraan yang mengakibatkan masalah tidak akan berujung (Hidayati, 2021).

Dikutip dari Merdeka.com, Dirjen Bimas Islam Kamaruddin Amin memberikan komentar mengenai tingkat perceraian yang semakin meningkat di Indonesia ini bahwa jumlah perceraian di Indonesia rata-rata mencapai seperempat dari dua juta jumlah peristiwa nikah dalam setahun. Oleh sebab itu, pihaknya terus berupaya men ekan angka perceraian melalui program penguatan ketahanan keluarga. Amin menjelaskan bahwa pihaknya juga membangun sinergi dengan Badan Penasihat Pembinaan dan Pelestarian Perkawinan (BP4). Amin juga mengatakan bahwa program penguatan ketahanan keluarga tersebut dilakukan dengan adanya kegiatan bimbingan perkawinan yang bersinergi dengan mitra strategis seperti BP4. Memang perceraian di Indonesia menunjukkan angka yang bukan hanya akibat Covid-19 saja, namun angka tersebut makin meningkat pada masa pandemi Covid-19 (Fauziah et al,, 2020).

Menurut Hidayati, L. (2021), dalam "Fenomena Tingginya Angka Perceraian Di Indonesia Antara Pandemi danSolusi," Khuluqiyya, agama Islam memperbolehkan perceraian meskipun dibenci oleh Allah Swt., namun cara-cara yang baik dalam pencegahan perceraian perlu ditempuh (Hidayati, 2021). Upaya menekan perceraian bisa dilakukan dengan menggandeng para tokoh agama masyarakat untuk memberikan bimbingan sertailmu agama menjelang pernikahan kepada muda-mudi calon pengantin di 
masa yang akan datang. Sebab dalam hubungan rumah tangga tentu perma salahan-permasalahan baru akan muncul baik itu dari segi keluarga, ekonomi, pasangan sendiri danlain sebagainya. Jika ditanami ilmu agama tentu risiko terhadap perceraian akan semakin berkurang (Hidayati, 2021).

Menurut Fauziah, A. S. N., Fauzi, A. N., \& Ainayah, U. (2020), dalam "Analisis Maraknya Perceraian Pada Masa Covid-19," Mizan: Journal of Islamic Law, perceraian di Indonesia tidak dapat sepenuhnya menerapkan hukum Islam secara lisan tetapi dibutuhkan perundang-undangan untuk mengatur agar salah satu pihak tidak dirugikan (Fauziah et al., 2020). Perkawinan merupakan pondasi keluarga dan perceraian putusnya hubungan suami-istri sehingga dibutuhkan penguatan hukum Islam dan sekaligus perundang-undangan tentang perceraian seiring pandemi Covid-19 di Indonesia (Fauziah et al., 2020). Sebab, perceraian tanpa melibatkan aspek hukum perundangan-undangan yang berlaku dapat membawa dampak-dampak burukyang tidak diharapkan (Rodliyah, 2014).

Ikhtiar lain yang bisa dilakukan untuk meminimalisasi perceraian yang semakin meningkat pada saat pandemi Covid-19 yang mungkin dirasa cukup sulit, seperti saling memahami satu sama lain, membicarakan atau mendiskusikan solusi yang bijak dengan cara tidak emosional, lebih menghargai pendapat yang berbeda dari anggota keluarga yang lain agar tidak terjadinya kesalah-pahaman. Karena dalam hal berumah tangga tentuakan selalu ada cobaan dan ujian saatmenjalaninyakarena saat berumah tangga tidak hanya senang bersama namun dalam keadaan sulit tetap harus bersama serta melakukan kegiatan bersama-sama dengan keluarga, di mana dengan melakukan kegiatan bersama akan membuat relasi atau hubungan keluarga menjadi lebih erat. Komunikasi intensif juga harus dijaga, adanya komunikasi dapatmembantu satu samalain menjadi saling pengertian dan saling memahami (Radhitya, 2020).

Bagi Subardhini, M. (2021), dalam "Perceraian Di Masa Pandemi Covid-19: Masalah dan Solusi," Politeknik Kesejahteraan Sosial Bandung, secara umum faktor penyebab perceraian pada masa pandemi Covid-19 terjadi karena adanya konflik dalam rumah tangga yang disebabkan oleh permasalahan ekonomi, ketidakseimbangan aktivitas dan waktu bersama, KDRT, beruba perubahan pola komunikasi, dan faktor usia dalam membina rumah tangga (Subardhini, 2021). Masyarakat dan keluarga juga memiliki peran dalam menekan terjadinya perceraian karena merekalah yang mempunyai hubungan kehidupan dengan kedua belah pihak. Dukungan dari keluarga dan masyarakat ikut andil dalam hal ini, seperti dengan melakukan kegiatan keluarga atau kemasyarakatan secara bersama-sama dengan menciptakan lingkungan yang baik, serta saling menjaga silaturahmi (Subardhini,2021).

Pencegahan merupakan solusi terbaik untuk menekan angka perceraian di Indonesia sehingga perlu meningkatkan peran kontrol Kementerian Agama, pengawas agama, para ulama dan kiai, tokoh masyarakat, dan perguruan tinggi dalam melakukan sinergi bagi pencegahan angka perceraian di Indonesia(Hidayati, 2021).

\section{SIMPULAN}

Covid-19 yang menghebohkan dunia, termasuk di Indonesia tentu memiliki dampak negatif bagi dunia, negara serta terhadap rumah tangga. Salah satu penyebabnya adalah perekonomian yang semakin menurun sehingga dirasa kurang dal am nafkah keluarga yang menyebabkan sering terjadinyaperdebatan serta kekerasan dalam rumah tangga bahkan hingga berujung pada perceraian. Perceraian telah diatur dalam Islam dan perundang-undangan di Indonesia. Hukum asal perceraian menurut Islam adalah makruh. Perceraian diperbolehkan atas dasar manfaatnya lebih banyak dari pada sisi mudhorot. Namun, perceraian merupakan suatu perbuatan halal yang Allah benci sehingga sebaiknya perceraian tersebut dapat dihindari dengan berbagai upaya pencegahan sebagaimana ditekankan dalam perundang- 
Perceraian Akibat Dampak Covid-19 Perspektif Hukum Islam dan Perundang-undangan Di Indonesia Robiah Awaliyah dan Wahyudin Darmalaksana

undangan di Indonesia. Penelitian ini diharapkan memberikan manfaat bagi khalayak luas umat Islam. Diakui penelitian ini memiliki keterbatasan dalam memberikan perspektif sehingga dibutuhkan pendekatan yanglebih holistik. Penelitian ini merekomendasikan upaya-upaya pencegahan perceraian di masa pandemi Covid-19 melalui peran pemerintah, tokoh agama, masyarakat, keluarga hingga dengan kesadaran sendiri.

\section{DAFTAR PUSTAKA}

Abdi, M. N. (2020). Krisis Ekonomi Global dari Dampak Penyebaran Virus Corona (Covid-19). AkMen Jurnal Ilmiah, 17(1), 90-98.

Abror, H. K., \& MH, K. H. A. (2020). Hukum perkawinan dan Perceraian. Ladang Kata, Bantul Yogyakarta.

Anwar, S. (2015). Tinjauan Hukum Islam Terhadap Perceraian Atas Kehendak Orang Tua (Studi Kasus di Desa Grinting Kecamatan Bulakamba Kabupaten Brebes). UIN Walisongo.

Asmuni, A. (2016). Perceraian dalam Perspektif Fikih Klasik dan Kompilasi Hukum Islam. Warta Dharmawangsa, 48.

Azizah, L. (2012). Analisis Perceraian dalam Kompilasi Hukum Islam. Al-'Adalah, 10(2), 415-422.

Burlian, F. (2019). Eksistensi Perkawinan Dan Perceraian Menurut Hukum Islam Dan Pasca Berlakunya UU NO. 1 Tahun 1974. MIZAN, Jurnal Ilmu Hukum, 8(2). https://doi.org/10.32503/mizan.v8i2.669

Darmalaksana, W. (2020a). Formula Penelitian Pengalaman Kelas Menulis. Jurnal Kelas Menulis UIN Sunan Gunung Djati Bandung.

Darmalaksana, W. (2020b). Metode Penelitian Kualitatif Studi Pustaka dan Studi Lapangan. PrePrint Digital Library UIN Sunan Gunung Djati Bandung.

Fauziah, A. S. N., Fauzi, A. N., \& Ainayah, U. (2020). Analisis Maraknya Perceraian Pada Masa Covid 19. Mizan: Journal of Islamic Law, 4(2), 181-192.

Hadiwardoyo, W. (2020). Kerugian Ekonomi Nasional Akibat Pandemi Covid-19. BASKARA: Journal of Business \& Entrepreneurship, 2(2), 83-92.

Halodoc, R. (2018). 7 Efek Buruk Perceraian Bagi Anak. Halodoc.

Hamid, H. Z. (1988). Pokok-Pokok Hukum Perkawinan Islam dan Undang-Undang Perkawinan di Indonesia. Bani Cipta.

Hasrul, M. (2020). Aspek Hukum Pemberlakuan Pembatasan Sosial Berskala Besar (PSBB) Dalam Rangka Penanganan Corona Virus Disease 2019 (Covid-19). Jurnal Legislatif, 385-398.

Herdiana, D. (2020). Konstruksi Konsep Social Distancing dan Lockdown dalam Perspektif Kebijakan Publik. Inovasi Pembangunan: Jurnal Kelitbangan, 8(02), 107.

Hidayati, L. (2021). Fenomena Tingginya Angka Perceraian Di Indonesia Antara Pandemi dan Solusi. Khuluqiyya, 3(1), 71-87.

Indonesia, Y. P. P. / P. A.-Q. D. A. R. (2009). Al-Qur'an dan Terjemahnya. Syamil Qur"an.

Khaeruman, B., Nur, S., Mujiyo, M., \& Rodliyana, D. (2020). Pandemi Covid-19 dan kondisi darurat: Kajian hadis tematik. UIN Sunan Gunung Djati Bandung.

Liputan6.com. (2020, September). Ada 989 Kasus Perceraian di Madiun Selama Pandemi COVID-19.

Marison, W. (2020, September). Selama Pandemi Covid-19, Kasus Perceraian di Jakarta Timur Mencapai Angka 900. Kompas.Com.

Masriani, Y. T. (2014). Perjanjian Perkawinan dalam Pandangan Hukum Islam. Serat Acitya, 2(3), 128.

Nasruddin, R., \& Haq, I. (2020). Pembatasan sosial berskala besar (PSBB) dan masyarakat berpenghasilan rendah. SALAM: Jurnal Sosial Dan Budaya Syar-I, 7(7), 639-648.

PNH Simanjuntak, S. H. (2017). Hukum Perdata Indonesia. Kencana.

Radhitya, T. V., Nurwati, N., \& Irfan, M. (2020). Dampak Pandemi COVID-19 Terhadap Kekerasan dalam Rumah Tangga. Jurnal Kolaborasi Resolusi Konflik, 2(2), 111-119. 
Perceraian Akibat Dampak Covid-19 Perspektif Hukum Islam dan Perundang-undangan Di Indonesia Robiah Awaliyah dan Wahyudin Darmalaksana

Rasjid, S. (2012). Fiqh Islam (Hukum Fiqh Islam). Bandung: Sinar Baru Algesindo.

Riami, R. (2020). PERCERAIAN MENURUT PERSEPSI PSIKOLOGI DAN HUKUM ISLA M. Imtiyaz: Jurnal Ilmu Keislaman, 4(2), 124-145.

Rodliyah, N. (2014). Akibat Hukum Perceraian Berdasarkan Undang-Undang Nomor 1 Tahun 1974 Tentang Perkawinan. Keadilan Progresif, 5(1).

Rosele, M. I., Syed Jaafar, S. M., \& Ramli, M. A. (2013). Prinsip-Prinsip Halal Dan Haram Menurut Yusuf Al-Qaradawi. Halalan Thoyyiban Perspektif Malaysia.

Siregar, R. S. (2015). Dampak Perceraian yang tidaksesuai dengan Prosedur Perundang-undangan. FITRAH: Jurnal Kajian Ilmu-Ilmu Keislaman, 1(1), 161-176.

Subardhini, M. (2021). Perceraian Di Masa Pandemi Covid-19: Masalah dan Solusi. Politeknik Kesejahteraan Sosial Bandung.

Syaikh Al-Munawi. (n.d.). Faidh al-Qadir Syarh al-Jami' al-shaghir. DKi Beirut.

Tanamas, dr. B. (2020). inilah Masalah Kesehatan yang Bisa Terjadi Akibat Perceraian. Klikdokter.Com.

Yamali, F. R., \& Putri, R. N. (2020). Dampak Covid-19 Terhadap Ekonomi Indonesia. Ekonomis: Journal of Economics and Business, 4(2), 384-388. 